\title{
Mini Conference Class Based-Learning Toward University Students' Critical Thinking Development in Efl Classroom
}

\author{
Giorgi Janiashvili ${ }^{1}$, Gusti Milla Quaidy ${ }^{2}$ \\ ${ }^{1}$ Klaipeda University, Lithuania, g.janiashvili10@gmail.com \\ 2 State Islamic Institut of Bukittinggi (IAIN) Bukittinggi, Indonesia, GustiMillaOnaidy@gmail.com
}

(02021 by the authors. Submitted for possible open access publication under the terms and conditions of the Creative Commons
Attribution-ShareAlike 4.0 International License-(CC-BY-SA) (https://creativecommons.org/licenses/by-sa/4.0/)
d DOI: bttps://10.30983/mj.v1i1.5185
\begin{tabular}{|c|c|c|}
\hline Submission: April 25, 2021 & Revised: May 29, 2021 & Published: June 30, 2021 \\
\hline
\end{tabular}

\begin{abstract}
Abstrak
Tujuan dari penelitian ini adalah untuk mengetahui pemanfaatan pembelajaran berbasis kelas konferensi untuk mendorong pemikiran tingkat tinggi mahasiswa, terutama di kelas Bahasa Inggris sebagai Bahasa Asing (EFL). Penelitian ini dilakukan karena sebagian besar mahasiswa tidak suka banyak berpikir ketika dosen memerintahkan suatu diskusi di dalam kelas. Sebagian besar mahasiswa memilih untuk diam selama diskusi berlangsung, sedangkan mahasiswa harus lebih kritis dalam memikirkan setiap masalah atau diskusi yang muncul. Untuk mengatasi kendala tersebut, peneliti mengusulkan suatu metode yang dapat meningkatkan berpikir tingkat tinggi mahasiswa melalui pembelajaran berbasis conference class.
\end{abstract}

Kata Kunci: Konferensi Berbasis Kelas, Mahasiswa Universitas, Berpikir Kritis.

\begin{abstract}
The objective of this study is to investigate the utilizing of conference class based learning to encourage university students' high order thinking, especially in English as Foreign Language (EFL) classroom. The study is conducted because most of students do not like to think a lot when the lecturers order a discussing in the classroom. Most of the students decide to keep silent while the discussion is being held, whereas university students must be more critical in thinking any problems or discussion appeared. To solve that constraint, the researchers propose a method which can increase university students' high order thinking through conference class based learning.
\end{abstract}

Keywords: Conference Class Based, University Students, Critical Thinking.

\section{Introduction}

University students are expected to have capability to face the demand of the real life. Students can no longer necessarily compete in the "real world"... From the statement, it illustrates how students will be in the future (Acai, Anita, et all, 2013). The causes occurs because students are actually required to have skills in order to compete later which the skills include problem solving, leadership, communication and teamwork. On the other hand (Chinedu, C.C., Kamin, Y, 2015), they need to be able to develop capacities to learn continuously through thinking and reasoning, problem solving, decision making and interpersonal competence. Both experts implicitly define that the students expectedly do not only concern on the course taken by them, but they also need to focus on being critical thinking (higher-order thinking) in some lessons which order the students to think more critical or to strive them in problems solving which order in some chapters of the lessons. It is because there are some chapters which need deep discussion.

In addition, students are not the only actors to succeed the education, but lecturers also have big role in designing classroom toward the students' learning output. They need 
designing teaching method which can increase the students' creativity or interactive in classroom included developing their higher-order thinking.

English as Foreign Language (EFL) Classroom nowadays has been already challenging for particular teachers because teachers are encouraged to provide the students within higher order thinking activity. In the context of higher order thinking, the university students must optimize their ability in thinking, analyzing or being creative thinking in some subjects. However, there are some major problems appear in EFL classroom, those are lack of capacity in thinking, being creative, analyzing or solving a problem during their learning process. It can be seen in the common case during learning English grammar. They are given simple present tense as the learning subject. They will be difficult to analyze reading text based where the text states the used of simple present tense with narration.

Based on the problem appeared, the researcher is willing to implement Mini Conference Class Based-learning. This classroom activity is expectedly providing an impact towards students' higher order thinking (HOT)( Kakar, Ahmad Fawad et al, 2020). Teaching is an innovative approach that allows students to become active participants and show creativity in their learning before, during, and after class. It means lecturers have an essential responsibility to consider the best teaching method in order to stimulate the students in classroom activity. Mini Conference class based-learning cannot only be used in English class but it can also be used in other lessons. Also, this model is not only a teaching method, but it is also the classroom model where the students will be asked by the lecturer to sit in a conference atmosphere.

\section{A Concept of Higher Order Thinking (HOT)}

Most of educators (included lecturers) have been familiar with Higher Order Thinking concept. HOT means handling a situation that we have not encountered before and is generally recognized as some combination of the above characteristics (Mainali,Bhawan Prasad, 2012). It means that The students are expected to be creative thinking and more critical thinking while learning process in certain subjects because they will be in workforce after graduating of the collage so that they are prepared to be creative thinking, critical thinking, and also able in problem solving. S.Ahmad, et al (2017) also strengthen that HOTS consists of two components namely critical and creative thinking skills. HOTS is proceed after those components are elaborated.

\subsection{Critical Thinking}

Critical thinking means students are emphasized to have ability in problem solving. The students can actualize the component by practicing. They are supposed to solve any kinds of higher level tasks in certain subjects. One of the examples is the students have already known the used of present continuous. Even though they have already understood the material, they need to increase the level of the material. They can use analyze text based to increase the level higher.

\subsection{Creative Thinking}

Creative thinking means students are asked to have capability in finding another way to solve problem. Additionally, they also need to be creative to solve any problems. One of the examples is the students have been taught by their lecturer about present continuous 
by giving them a formula. Thus, the students must be creative to find other way in comprehending the subject. In this case, the formula can be shortened by comprehending the context (it is used in on going activity by using Ving).

\section{Problematic Faced by University Students}

Nowadays, students in higher education do not only effort their matter of lesson but they also have other activities out of the classroom, such as joining organization, joining event, etc. It is one of the factors that can influence the students' aim in critical thinking and creative thinking. It is because whether the students seldom join classroom process or the students do not focus in their learning process.

In another case, several students are still difficult to become critical thinker and creative thinker. It ensues because they are seldom given activity that emphasizes them to think higher. The obstacle do not only appear from the students but it also causes from the lecturers. They commonly conduct an activity where the students are easy to do cheating so that it is useless to enhance the students' HOT.

Further problematic is most of the students are lack of reading habit. They seldom visit the library which is placed in their collage so that they just have limited information and knowledge. It can impact their learning performance in the classroom when they are given any kind of tasks. Besides, they can access any information in the library to increase their critical thinking improvement. It occurs because reading a lot can influence the students' thought.

The problems above impact the students in being difficult in critical thinking and creative thinking (Hadi, Samsul et al, 2018). In modern concept, education becomes one of the means for preparing students to encounter every challenge of the modern era. It means that they are prepared to be more critical thinker and creative thinker to have capability to encounter themselves in the next level of life.

\section{Basic Definition of Conference}

In $21^{\text {st }}$ century, there are various kinds of teaching method and classroom management that can be provided by all of the educators (included lecturers). One of them is developing mini conference class based learning which can be recommended for the lecturers (gsa.govcdnstaticVarious_conference, 2018). A conference is a symposium, seminar, workshop, or any other organized and formal meeting, whether conducted face-to-face or via the internet, where individuals assemble (or meet virtually) to exchange information and views or explore or clarify a defined subject, problem, or area of knowledge, whether or not a published report result from such meeting. It defines that the conference is a meeting where all of the participant must prepare any kind of condition before joining the conference.

The conference model can be applied as the teaching method and classroom model in university with several suitable subjects that have deeper discussion. It occurs because the university students will prepare themselves before coming to the class by comprehending the materials which have been given.

The researcher proposes Mini Conference as the model of learning process in the classroom because it will invite the students to be more active in thinking and be more creative in thinking. Additionally, the model can be only used in several subjects which have 
deep discussion, such as Teaching English as Foreign Language, Learning grammar with narrative, and other general subjects.

\section{A Concept of Mini Conference Class Based Learning}

Mini Conference Class Based-Learning is a teaching style in EFL classroom which it will activate students' participation because through this teaching style, students will be required to do some activities(Sivilotti, Paolo A. G and Weide, Bruce W, 2004). The purpose is to show the academic life experience, which students can see the interplay from these various responsibilities. It obviously describes how it can give an opportunity to students to experience an academic learning activity. This learning style is also to gain university students' critical thinking and creative thinking because students will be offered by lecturers to finish their task by comprehending in group before the students attend to EFL classroom. Additionally, students are not only asked to comprehend the subject that the students are also required to present in the classroom then, they also need to read a lot about the subject. It means they need to strive themselves to acquire their lesson and they also will experience the learning process well. Learning process is not only an activity in classroom, it is also an activity where they experience the step in getting the knowledge, such as finding books, discussing, reading a lot, etc. It occurs because the great learning is when the students construct the lesson by themselves.

The mini conference class based learning will impact the students' HOT based on these following discussions:

\subsection{Critical Thinking through Mini Conference Class Based Learning}

Being critical thinking is really needed to all of students, especially for university students who have higher education. However, most of them are lazy to think higher. It occurs because they are not usual to think a lot. The problem arises because they seldom get task which ask them to think higher.

Based on the case arise, Mini Conference class based learning is really necessary in impacting the students' critical thinking performance because the students will find kinds of references in any sources, such as in library, e-book, internet, etc. It means they will try to construct the knowledge by themselves.

Therefore, Mini conference class based learning can give impact to the students' critical thinking performance. They will be set by the lecturer into a group. Then, they need to prepare the paper based on the themes which have been given by the lecturer. All of students must do the paper with their title. This model is almost similar as discussion model, however in discussion, the students are not asked by the lecturer to prepare their title based on the given theme. They only need to discuss in a group with similar theme and they also just sit in the common seating position. 


\subsection{Mini Conference Class Based Learning toward Students' Creative Thinking}

Being creative thinking means that students must have capability in finding another technique in creating something simpler or creating something more interested.

This recommended teaching method does not only give impact to university students' critical thinking performance, it also impacts to the students' creative thinking performance. It happens because this model emphasizes the students to think how to make the presentation well. They also need to be able in answering questions which will be addressed by the audience or other participant in the room. It means they need to learn how to elaborate in a group by giving a responsibility each of participants in a group

The lecturers also must emphasize the students to do the task independently. It means that they may not be allowed to gain any helps from another group. The lecturers can realize it by selecting the paper which will be presented then. It means that another group needs to focus on their duty because the selected paper will get additional score.

\subsection{Mini Conference Class Based Learning toward Students' Problem Solving Competence}

The further impact of utilizing mini conference class based learning is the university students will have a capability in solving problems. The problems mean that they will be trained to be independent by finding the material and finding the answer that will be addressed by the audiences.

It highly gives positive impact to the university students' future life. It occurs because they will be in higher level life. One of the examples is they will find the job after graduating from the university so that they must be able in solving problem competence.

\section{Rule of Procedures in Conducting Mini Conference Class Based Learning}

After considering the impacts of the utilizing mini conference class based learning, the researcher will propose the rule of procedure (RoP) that can be applied by various educators included lecturers in the classroom. Here are the following procedures:

1. All participants will make a title based on the theme that has been given by the lecturers.

2. The paper must be submitted 3 days before the learning. It is because the lecturers will analyze the paper whether it is important to be discussed or it is not supposed to be discussed (can be discussed by themselves).

3. The lecturers will select the papers which have been submitted to be presented. The number of paper that will be selected depends on the condition. Additionally, the amount of participants in a group is depended on the lecturers. It is considered by the time allocation and the subject. The time allocation for each group is at least 15 minutes (included the questions from audiences) 
4. The group which has a chance to present should acquire whole the material. The members in the group must understand about the topic because the lecturers will ask the students to present randomly.

5. The presenters use English as the lingua franca in that mini conference. It occurs because it can enhance the students' capability in speaking English.

6. In mini conference class based learning, the keynote speaker that will address the general material is the lecturers of the subjects. They will present the topic based on their titles which is taken from the theme. They will deliver the material after all of the presenters finished to present their presentation based on the topic or title that they have chosen. It is contrast in common conference where it has number of keynote speakers that come across the countries or across the regions and the keynote speakers also present their papers earlier in shift.

7. In conducting mini conference, there are many aspects that should be considered. The aspects will impact whether the model is effective or it is not effective. One of the aspects is the seating arrangement procedure. Seating arrangement is needed to be considered because it will impact the students' attention during presentation. They will more focus on the presentation because the lecturers will be easier in controlling the students. In this case, the seating position should be in half-circle. It is because all of participants will give more attention to the presenters.

Here is the seating position model of the mini conference class based learning which is proposed by the researcher.

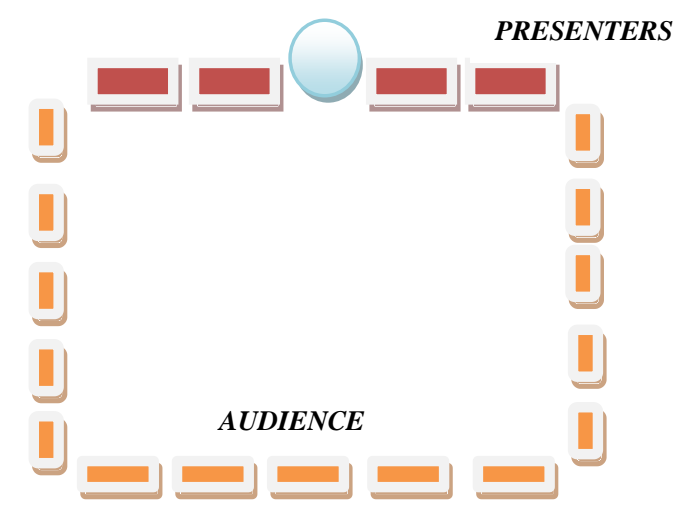

Illustration of seating arrangement in mini conference class based learning

The red layer is the presenters whose papers which have been selected. The presenters will present their paper by using power point that will be presented using in focus (the white circle). Additionally, the orange layer is the audience that will participate in the conference.

8. The papers or groups who are not selected yet become audiences. They role is they must address a questions to the group. The lecturers will ask the audiences to address the 
question randomly. It means that all of the audiences must pay attention to the presentation.

9. After the first group presents the paper, the next group will take the turn. During the first group present the paper; the next group becomes a audiences where they have a role to address questions also.

10. All of the audiences must write the point (conclusion) of the topics which are presented by the group personally. It is also conducted by the groups who have presented the topics. They will be audiences after presenting the topics so they need to do the same duty.

11. The conclusion of each topic that the audiences write must be submitted because it will be marked by the lecturers. It is because the activity will increase the students' contribution in the classroom while their friends are presenting their papers.

12. The score is taken based on the presenters' comprehension of the materials and their competence in responding the audiences' questions. The score is not only taken to the presenters, it is also taken by the audience who address questions.

Therefore, those are the rule of procedure which is proposed by the researcher in conducting mini conference Class based learning. The RoPs have been considered based on the common procedures that have been ever conducted in several conferences.

The mini conference does not mean that it is the common conference but it has modified by the researcher simpler. It occurs because it will be easier for the lecturers and the students in applying the model (Tipka, Bradley, 2005). ${ }^{1} \mathrm{~A}$ mini-conference is an effective method of bringing the staff together, building cooperation and teamwork, and raising the overall achievement levels of the school (Tipka,2005)

\section{Conclusion}

Mini Conference Class Based Learning is the suggested teaching model and classroom model in enhancing university students' HOT (Higher-Order Thinking). This study is necessary to be discussed because it can help the lecturers to increase the students' capability in their thinking performance. They need prepare themselves to continue in higher life. It means that they must be able in problem solving, creative thinking and critical thinking. The components which are mentioned above is the crucial parts for the university students in enhancing their HOT since they are not a students in high school level anymore where they are not supposed to think to play together to their friends.

The suggested teaching method is easy to be conducted by the lectures. It is almost similar as the discussion teaching method, however in Mini Coference Class Based Learning has specific parts that the students must realize. Therefore, this method is really necessary in enhancing university students' Higher-Order Thinking (HOT).

\footnotetext{
${ }^{1}$ Tipka, Bradley, The Mini Conference: Crating Localized Opportunities for Professional Development, English Teaching Forum, 43(4),p3 (2005)
} 


\section{References}

Acai, Anita, et all. (2013). Exploring the Role of the University Students as an Experiential Learner: Thoughts and Reflections from 2013 Cohort of $3 \mathrm{~m}$ National Students Fellow. Students Fellows Feature Article, 2 (2013).

Chinedu, C.C., Kamin, Y. (2015). Strategies for Improving Higher Order Thinking Skills in Teaching and Learning of Design and Technology Education. JTET. 7 (2), p36.

Hadi, Samsul et al. (2018). The Difficulties of High School Students in Solving Higher-Order Thinking Skills Problems. The Journal of Problems of Education, 76(4), 521. httpswww.gsa.govcdnstaticVarious_conference_definitions_508.pdf, retrieved on October 29, 2018.

https://www.gsa.govcdnstaticVarious_conference_definitions_508.pdf, retrieved in October 29, 2018.

Kakar, Ahmad Fawad et al. (2020). Creative Teaching in EFL Classrooms: Voices from Afghanistas. Journal of Foreign Language Teaching and Learning, 5 (2), p159 (2020)

Mainali,Bhawan Prasad .(2012). Higher Order Thinking in Education. A Multidiciplinary Journal, 2 $(1), 6$.

S. Ahmad, et al. (2017). The Instruments of Higher Order Thinking Skills. Journal of Physics: Conference Series, 943 (2017) 012053, 2.

Sivilotti, Paolo A. G and Weide, Bruce W. (2004). Research, Teaching, and Service: the Mini Conference as a Model for CS Graduate Seminar Course. SIGCSE, p2 (2004)

Tipka, Bradley, 2005. The Mini Conference: Crating Localized Opportunities for Professional Development. English Teaching Forum, 43(4), 35. 